\title{
Survival in the Badlands: An exploration of disaffected students' uses of space in a UK secondary school
}

Thomas Ralph ${ }^{\mathrm{a} *}$ and Martin Levinson ${ }^{\mathrm{b}}$

${ }^{a}$ Graduate School of Education, University of Exeter, Exeter, United Kingdom; ${ }^{b}$ College of Liberal Arts, Bath Spa University, Bath, United Kingdom

Thomas Ralph (corresponding author),

Graduate School of Education,

University of Exeter,

St Lukes Campus,

Heavitree Rd,

Exeter.

EX1 2LU

t.ralph@exeter.ac.uk

Tel: 01392724762

ORCiD ID: 0000-0002-8232-4302

Martin Levinson,

College of Liberal Arts,

Bath Spa University,

Newton Park,

Newton St Loe,

Bath. 
BA2 9BN

m.levinson@bathspa.ac.uk

Tel: 01225875893 


\title{
Survival in the Badlands: An exploration of disaffected students' uses of space in a UK secondary school
}

\begin{abstract}
This article considers the understandings of space and place amongst a group of disaffected students, within an institution that had been in a state of flux over a number of years. It explores ways in which students are positioned by institutions into specific spaces, ways in which they use those spaces to challenge authority, and ways in which they appropriate both space and place to assert new, and often playful, identities.
\end{abstract}

The authors consider the meanings of the spatial behaviour of students through notions of space and place as developed by Doreen Massey, with reference to a Foucauldian understanding of power. In some ways the students might be perceived as being marginalised, victims of a hierarchical environment in which their status is low. Yet they also emerge as active agents, forging new interpretations of their surroundings, robust group identities, and reinforcing ingroup relationships through spatial behaviour.

Keywords: space; place; identities; school ethnography; student resistance

\section{Introduction}

Users of school space attribute multiple meanings to school and these affect how spaces are claimed. Although this space is often considered via the purposes of those who have a tactical and political advantage, the students who inhabit a school do not necessarily endorse the form in which a school environment is presented to them and can, and do, resist prescribed representations (Schmidt 2013). In particular, students resent adult intrusion of social spaces (Daniel and Gustafsson 2010). As far back as primary school, children will find means by which to evade the limits imposed on their use of space and interaction, modifying and subverting the classroom space to their own interests (Catling 2005), and through conspicuous occupation of territory, children can make their presence felt and publicly assert their collective identity (Hall, Coffey, and 
Williamson 1999), with particular spaces enabling the development of specific identities (Allen 2013). However, identical spaces are frequently understood and experienced differently by different students: the interpretation of space is mediated by a student's self-concept and identity, and the formation of identity, as related to the school environment, is multifaceted (O’Donaghue 2007).

Students become agents in public spaces by contesting the meanings and division of school spaces imposed by others. (Schmidt 2013). This identity encompasses an understanding of self as a subject and a grasp of the means by which to implement this subjectivity across a diverse and often exclusive terrain. The physical landscape changes the ways in which students enact these civic identities, with specific areas claimed by particular groups (Tupper et al. 2008). Meanwhile, the selection of some places allows for processes not just of resistance but of disidentification (MorrisRoberts 2010; Skeggs 1997), a conscious process by which students can distance themselves from the cultural norms and values of the institution. Disidentification can take the form of either an overt resistance to school or a superficial, tactical, compliance to allow more subtle acts of resistance (Schmidt 2013).

This article explores the meanings to be drawn from the spatial behaviour of a group of marginalised youngsters in an English secondary school. It emerged from an ethnographic study that followed a group of students, inviting them to photograph different places around the campus then exploring the meanings of those places through conversation and interviews. Feeling disempowered within the school community, the students sought to express defiance and assert more robust identities through the appropriation of specific spaces around the campus. To the outsider, these spaces often seemed marginal, either abandoned or with little practical utility. However, the students imbued these spaces with new meanings, recognisable only to their in-group. They were 
a means of establishing an in-group (Tajfel and Turner 1986) with its own codes and alternative values.

\section{Constructing Identity Through Narratives of Place}

Finding a link between a sense of belonging in the classroom and a desire to construct and occupy informal spaces around school, Brown (2017) noted that the youngsters in lower 'ability' sets tended to occupy peripheral spaces. The meaning applied to such spaces is not fixed and may fluctuate with resistance ensuing from the construction of alternative meanings and narratives of place. There will inevitably be contested and dominant histories of place (Massey 1995). The main reason young people give for liking specific places is bound up with the functions of those places, and they will generate new stories of place that alter those functions (Christensen, Mygind, and Bentsen 2015). As Lefebvre (1991) proposed, space is both an outcome of and conduit for the exercise of power. The ability to claim ownership of areas, the assertion of what is ours not yours ensues from changes to behaviour / actions within given territories (Sack 1986).

In Schmidt's study, students were reported as reclaiming certain spaces, within which they experimented with new identities. Soja (2010) suggested that spatial reappropriation is fundamental to rupturing discourses that restrain access to space and authority. These moments of spatial re-appropriation were meaningful instances of dissent that destabilised the dominant sense of place. Spaces created for explicit purposes amass extra, unintended, functions once they are occupied and experienced. Students appropriate spaces for their own recreation that were designed for something else (O’Donaghue 2007). Meanwhile, one implication of Reay's 2007 study was that 
spaces in schools perceived as abject or stigmatised can be rehabilitated - and in the light of the evidence below, even fetishized.

The empirical work discussed here needs to be considered through a wider theoretical lens around space and place which will be elaborated in the next section.

\section{Theorising Space, Place and Power}

The use of space and allocation of specific places in schools reveals the hierarchical relationships within institutions. From the outside, it is easy to view the appropriation of marginal space as being indicative of disempowerment, when the situation is, actually, more complex. Actions can suggest both powerlessness and agency at the same time. However, before seeking to understand the behaviour of the young people involved in the research reported here, it is necessary to clarify conceptualisations of 'space' and 'place'.

In developing his concept of 'ThirdSpace', Soja rejected the tendency among Marxist geographers to privilege the social over the spatial. Instead, he contended that there was a dialectic based on mutual relations, by which geography shaped class as much as class shaped geography (Borch 2002; Soja 1996). This link between geography and class facilitates a far more dynamic model, one that is more fluid, open to multiple and unpredictable interactions.

In keeping with this notion, Casey (1996) argued that space and time arose from the embodied experience of place, while Massey (2005) proposed spatialised subjectivity, recognising space as the sum of heterogeneous interrelations that are always in the process of construction. Such conceptualisations of space as open, multiple, relational and unfinished allow for the possibility of politics and political 
action. Space becomes a product of social relations and the act of travelling about it implies a contribution to its ongoing fabrication:

\footnotetext{
"If space is ... a simultaneity of stories-so-far, then places are collections of those stories, articulations of the wider power geometries of space. Their character will be a product of these intersections within that wider setting, and what is made of them."
}

(Massey 2005, 130)

Massey viewed both place and space as arising from active material practice. When one arrives in a place, one becomes enmeshed in the plexus of stories from which that place is made. Place is defined by these intersections within the wider setting, which entail both connections and relationships that are and are not established; place is about exclusion as well as inclusion. Movement is always temporal as well as spatial, and the moment a place is vacated it moves on, its character altered. Massey eschewed the idea of place as having a predetermined identity, emphasising, instead, its thrown togetherness, seeing it as a constant process of negotiation. Through Massey's understanding of the distinction between space and place, we can understand the interaction between the local practices that occur in a school and the wider discourses to which that school and its occupants are subject can be understood. Students, teachers and the rest of a school's population bring with them their histories and relationships creating a specific place within the broader national, political context of the education system and its demands on those individuals.

Before moving on to further issues around power and space it is helpful to consider how pupils can be discursively constituted within school hierarchies. Youdell (2006) describes the 'ideal' pupil as an acceptable learner. School discourses around ability and conduct mediate one another, restricting the potential of pupils judged to be non-ideal (Gillborn and Youdell 2000, 2004; Youdell 2004, 2006). The ideal, or at least 
tolerable, student does not fight, jump over desks or throw chairs. These are challenges to authority that are incompatible with being a learner in school (Gillborn 1990) and pupils that exhibit such behaviour may be constituted as unacceptable (Youdell 2006). Whilst this unacceptable learner is still intelligible within the discursive realities of school there may be a further category of student; the impossible learner. The judgement as to whether a student is unacceptable or acceptable is formed on the basis of a teacher's relationship with an individual student. Pupils are situated within a hierarchy in school and are subject to the normalizing judgement of that institution. The pupil that transgresses is constituted through discourses that specify their deficits (Youdell 2006).

Given these hierarchical power dynamics within schools, there is an almost inevitable tendency for them to operate as sites of resistance. In the context of the specific situation of the participants in this study, it is understandable that the language with which their understandings were framed drew on synonyms for defiance, resistance and combat. Becoming an ontological condition, such language comes to represent the low-impact conflict that permeates the most routine features of everyday existence (Goodman 2010). Indeed, metaphors of war are liable to be employed by groups in opposition to authoritarian power (Deleuze 2004; Deleuze \& Guattari 1988; Sibertin-Blanc 2010). The language in itself becomes a means of challenging and disrupting prevailing power structures. As demonstrated by Foucault $(1988,2003)$, resistance operates through such language as much as it does through action.

De Certeau (1984) framed power relationships through the concepts of strategy and tactics. Strategies are actions that create systems and totalizing discourses through the establishment of a place, and they require the hope that the instituting of a place erodes the effect of time. Tactics were defined by De Certeau as a calculus that cannot 
count on delineated spaces or on boundaries that might distinguish the 'other'. De Certeau postulated that tactics belonged to 'others' and that the circumscription of space could be perceived as a triumph of space over time. Tactics are contingent on time, selected in opportunistic ways with only temporary benefits.

Strategy is static, pertaining to structure, whereas tactics are the practice of the everyday as it engages with that structure. The implication of this is that power exists as a monolith on the one hand, while, on the other, exist the tactics of the weak. This view of strategy represents a colossal overestimation of the unity of the powerful and the coherence through which order is produced (Massey 2005), unintentionally diminishing the capacity of the weak and concealing their complicity in power.

Power relations should not, then, be conceptualised as a simple dichotomy between power and resistance. Furthermore, the rendering of power and resistance as a binary split between space and time has as its inevitable corollary a lack of ability to examine the relationship between them (Sharp et al. 2000). Similarly, the spatialisation and marginalisation of resistance removes any implication or responsibility for power, ultimately presupposing a politics from a geography (Massey 2005). Foucault (1982) suggests that in order to understand exactly how power relations operate, it is necessary to investigate resistance instead of attempting to analyse power from the perspective of its own internal rationality, stating that this approach is more empirical and involves greater links between theory and practice.

Given this conceptualisation of power and resistance, young people in schools cannot be absolved from responsibility for the manner in which power operates. There is clearly going to be an inequitable spread of power between the staff and students within a school. The extent to which this inequality exists will change according to location and other particular circumstances. In attributing meanings to interactions, it is 
necessary to consider whether the students in schools are simply transgressing boundaries opportunistically in time - as De Certeau might suggest. Alternatively, one might focus on a spatial component to their behaviour, as Massey would prefer. Either way, it is evident that resistance is key in the creation of place.

\section{Research Questions}

The research reported here was carried out in a secondary school in the South of England that had been identified as 'underperforming' by Ofsted (Office for Standards in Education) inspectors. According to the UK Government's English indices of deprivation website, updated in 2015 , the pupils of the school are largely drawn from an estate which is located in one of the $20 \%$ most deprived areas in the country. Viewed as failing by the broader community, the school contains a large number of students perceived to be disruptive and disaffected. At the time of the study the school building was in the process of being demolished and rebuilt on the same site. It was against this background of instability that the research took place.

The research questions addressed within this report are:

- How does the quality of the environment affect the participants?

- How do the participants occupy space in order to create the kind of place that they want school to be?

\section{Methodology}

Ethnography was considered a suitable approach to address the research questions due to their focus on emplacement and the manner in which participants engaged with their environment (Pink 2009). Nine boys and eleven girls aged between 14-16 participated, all White British apart from two members of the local traveller community. The 
participants were situated in low achieving classes. Fieldwork took place over twelve months with visits taking place twice weekly during term time.

The research questions, focusing on the creation of place and the ways in which place was experienced, required methods that neither prioritised the visual nor were reducible to it (Pink 2009). Whilst more traditional approaches to participant observation and interviewing attend to cultural and social systems, values, organisation and more, they can be restricted by their lack of responsiveness to experiential facets of ethnography. In order to address these issues, a variety of methods were chosen in order to collect data and maximise the engagement of these methods with the creation of place.

Observations, interviews and walks with the participants were carried out, while participants were also invited to create photographic representations of places and spaces around their school.

Interviews were semi-structured, enabling the participants to talk around themes using their own frames of reference, drawing on concepts and meanings with which they were conversant. One key benefit of this approach was that participants have the ability to contest the preconceptions of the researcher and emphasise the standpoint of the interviewee (May 2001). Interviews were also conducted in groups, moderating the authority of the researcher, permitting participants to take control of the place where the interview occurs (Kamberelis and Dimitriadis 2013). Photograph elicitation interviews were also used, enabling reflection on aspects of experience that might not normally be considered in interviews (Rose 2007). This approach is useful in countering the transience of aesthetic and sensory experience. Here the researcher and the participant may discuss differing understandings of an image, appreciating that the meanings any image may have are constructed by both the creator of the image and its viewer (Harper 1998). 
The feelings of alienation and resentment among the participants created certain ethical dilemmas for the researcher. Trust was gained in part through maintaining distance from staff and participants rarely saw the researcher conversing with teachers other than when asking for permission to enter classrooms. Over time the students began to recognise that the researcher was not a member of staff. It was difficult on occasion for the researcher to maintain 'neutrality', as apart from wishing to gain trust, he was often genuinely amused by the defiant acts of participants. He also felt sympathy for their view that their education was being undermined by the seemingly continuous change going on around them, both in the structuring of the school and in the physical landscape. In such circumstances, it is our view that research should be explicit about such sympathies, rather than feigning objectivity.

\section{Findings}

\section{Internalisation of the physical environment}

As already noted, the research took place at a time of sustained building work. Though many participants did not seem all that engaged in their studies, they remained extremely critical about the on-going work, suggesting it constituted a disruption to them. They were also keen to identify examples of low-quality building, providing photographic evidence. In discussing this evidence, they used metaphors connecting the shoddy environment to the school as an institution. A key metaphor they selected, repeatedly, to describe their surroundings was a rubbish bin. This term was often used to illustrate their feelings about the fabric of the building, as in this discussion about a key photograph:

Simon: That's what reminds us of the school.

Interviewer: The bin? 
Richard: Shit.

Simon: It's dirty.

Richard: That's like the school though.

Simon: School's a bin.

Interviewer: Why is that?

Simon: Coz it is... look at it... it's just terrible.

Richard: There's bricks falling down by the benches. Part of the bench has fell off.

Simon: That bench there, there IS no bottom bit.

Mark: It's just concrete.

Simon: It's just 2 concrete supports.

The rooms in the older part of the building, due to be demolished in order to make way for new buildings, were particularly reviled. Visible, unplastered brick on the inside signalled to the students that very little effort and investment had gone into the room. Participants stated that the rooms with plaster on the walls as opposed to bare brickwork felt cleaner. They felt that many of the rooms in the older part of the building let in very little light and were drab. Complaints were also made about the newer rooms that let in light but had no blinds, which caused problems when reading the board or watching videos. Some of the smaller computer rooms were criticised for being too hot.

Pedagogical practice is, in part, defined by the spaces that enable them to occur, both guiding and constraining them. Educational space itself composes a tacit form of teaching and this visible but obscure aspect of the curriculum is a significant force that gives form to the everyday activities taking place in school. In turn, this facilitates the creation of a specific and unique culture contributing to the manner in which individuals occupy and move through those spaces (Prosser 2007). The material space of a school, being more than just a context, silently contributes to the production of subjectivities and identities (O’Donaghue 2006). The participants interpreted the physical space that they were occupying as being literally rubbish. Particularly troubling was the manner in which this metaphor was developed to describe themselves. The shabby older buildings 
and ill-constructed new buildings were identified as being of little value and reflected their own worth. In fact, they described themselves as 'worthless' students. Their attitudes and behaviours could not be easily separated from the spaces that they inhabited.

Even in newer parts of the school evidence seemed to be selected in photographs that confirmed this. An example of this was the prominence given in one of the photographic exercises and subsequent interview to broken fixtures and fittings around the school. Even when no real risks were apparent, danger was often exaggerated:

Charlie: Health and safety I'm thinking!!

Brandon: Charlie, that isn't electrical.

Martin: It's coz they ain't finished the fuckin' school.

At times, there seemed another element, a certain delight in portraying the school environment as dangerous. It made it a wild place, a sort of badlands, where they, the disadvantaged, not very academic students, were like outlaws - not to be messed with and there was a certain status in this. This is an example of what Dorothy Smith (2002) might call the emergence of an 'institutional language', co-ordinating the subjectivities of the participants and emphasising their position in the hierarchy of the school as worthless, unacceptable or even impossible learners.

\section{Making the 'badlands' badder, and the re-appropriation of space}

These attitudes towards the physical environment were complicated by the changes to the building that were taking place as the participants moved into Year 11 and there was a noticeable adjustment in their behaviour. To some extent, all students across the years were engaged in damaging school property and the substance of the school building, but this behaviour was particularly prevalent amongst Year 11 students. Much of this 
behaviour centred on drawing on or scratching desks with compasses and scalpels, particularly in the more practical subjects where they had more access to an appropriate tool. This behaviour was almost constantly happening in the more practical sessions and was captured in research field-notes:

Brandon comes over and starts screwing a screw into the ghetto blaster's plastic grill that protects the speakers. It won't go in, so he uses an electric screwdriver instead. This still doesn't go in, but gouges out lines that run across the speaker grill. Later, he drills holes into the teacher's desk.

Such actions have a purpose beyond the act of defacing school property. Brandon was asserting his spatial identity as an occupant who cannot just be erased, recognisable through his choice of instrument to vandalise the institution:

Brandon - "You always know when I've been somewhere coz I've drilled holes. Or stuck a compass in". He takes a compass and walks around room throwing it into surfaces.

This could be seen as a type of subversive spatial act (Bell \& Valentine 1995). O'Donaghue (2007) claims that the hard architecture of the school resists human inscription, aside from the aerosol can, but the furniture of the school can be used to mark physical space as well. These acts of vandalism disrupt the conventional uses of the space and seem to act as a form of resistance to school power structures. They establish ownership, re-appropriating space. Such instances of dissent through subversive spatial acts destabilise the dominant sense of place.

They also make an environment about which they had previously complained seem still worse. The surroundings might disgust them, they might make them feel worthless, but there is also a defiant pride, revelling in a sense of survival in the 'badlands', and serving as a warning to others that this is their territory. Brandon might 
not be remembered by teachers or future students for his exam results, but he will leave a signature mark on the landscape, reminding people that he was here.

Youdell (2006) claims that people become who they are by being intelligible within specific discourses and there may be advantages to being beneath intelligibility if it is created by predominant social norms. An individual beyond normative discourse may prefer estrangement to developing intelligibility via norms that arrive from another source, ultimately accepting their constitution as 'other'. We can see this in the situation previously discussed: for Brandon to become an acceptable learner to his teacher these norms have to be understood in a way that is mutually discursively constructed. If a child does not accept the terms under which acceptable identities may be formed there are benefits to remaining unintelligible and beyond understanding, impossible in the eyes of their teacher. These attempts to survive in the 'badlands' are unintelligible behaviours, a refusal to abide by the norms expected of them.

\section{Hideouts - and the affirmation of intra-group relationships through the reclamation of marginalised space}

In one of the playgrounds there was a skip, and the Year 10 participants used this in order to escape from lessons. This was photographed by a number of the students whilst they were independently photographing the school. It was a place they went to for smoking. It was a good place to hide and 'skive off' lessons as long as you were quiet.

The rubbish that the skip contained was mainly discarded pieces of furniture and the students explained that they also spent time climbing into it, where they smashed things like light bulbs and bottles.

Interviewer: Have you climbed inside?

Simon: Deena was in there. 
Mark: I was in there on the same day as Deena and we.... for about an hour... we sat in there and we got all like the test tubes and smashed them.

Simon: Why?

Mark: Coz it was in the skip and we was bored!

Simon: What was in there?

Mark: Peter got this fat light bulb as well and threw it - and you could hear it sort of like steaming.

Simon: Was there cardboard in there? And you sat on that?

Mark: Cardboard, tables, chairs.

Interviewer: Why did you get in the skip?

Mark: Bored.

Simon: It's a good pace to skive, really.

Interviewer: Was it a break or lunch? Or during lessons?

Mark: During lesson.

Simon: It's a good place to skive though really, innit.

Mark: As long as you don't make noise. If you try and move everything goes!

Interviewer: As long as nobody chucks some more rubbish in!

Mark: That's what we... coz we was sat like just here in front of it and we was

hoping no-one else would chuck more rubbish in.

Interviewer: So you smashed some stuff up?

Mark: Coz we're ard? (sarcastically) I dunno...

Interviewer: Do you think they should have that skip there? Does it annoy you?

Simon: Not really.

Mark: If I can get in it and not get caught, I'm fine! There'll be no more hiding from me next year.

Participants suggested different reasons for hiding in the skip - boredom and avoiding lessons, as well as a place to go for a smoke. Interestingly, they agreed that once they were in Year 11, they would no longer do this, as they would need to focus on examination work. As for breaking things up, again there are two suggestions: being bored, and being 'hard'. The smashing of objects could be perceived as further damage to school property, part of the process of marking out territory through subversive spatial acts. However, as these items had already been discarded, it was a pretty 
ineffectual act, if that was the intention.

Perhaps, deeper reasons concerned the marking out of territory, such as the

reinforcing of group identity through the establishment of another place that belonged to them. It seemed significant that these participants were both surprised and indignant when told that other groups in the school also used this skip as a hideout. Having been certain that this place was another marker of their uniqueness within the school, the idea that other groups might also be using their hideout seemed to threaten the sense of uniqueness and in-group superiority (Tajfel and Turner 1986).

\section{Returning from the wilderness: The re-appropriation of safe spaces}

Once they progressed to Year 11, spatial behaviours changed among the group of Year 10 students who had previously occupied the skip. Photographs they took at this stage reflected their move to 'tamer' spaces, while subsequent conversations around the photographs revealed how they had made their mark on these new places. One particularly popular place identified by some students was the Drama Studio. The room was left open at break and lunch times and it was seen as a place where teachers would not go. Students could be free from interference and left to their own devices. The room was spacious, with a high ceiling. There were large black curtains covering the windows, which meant that the room was very gloomy. This was a private space away from the public, ball-game dominated playground. There were several nooks and crannies, places where it was easy to hide. Some participants came here at other times, too, skipping their scheduled lessons. This was a place they had discovered in Year 10, describing it in the following way:

Simon: Mark, do you know the little room bit? At the back? 
Mark: It goes into a big tunnel into a big thing and you can just sit in there making noise, and teachers come in and they can't see you. All you see is their feet and it's funny.

Now in Year 11 they were able to appropriate the drama-studio as one of their spaces. The other area that this group of students named as a place they liked to inhabit as they moved into Year 11 was the new library. Many of the students testified that the reason that they enjoyed going there was the relative comfort and warmth that it offered.

Interviewer: Is this a good place to come then?

Esther: Yeah, I love it up here.

Simon: It's well comfy and warm.

Jenni: It's quiet and warm.

Here they were able to sit on sofas, and it was easy to hide from the teachers by moving around the bookshelves. This was not a straightforward activity because the teachers were obviously aware that it could happen, and so students alternated between the roles of students who were hiding and students who were half working and half being amused by the 'game' of watching their classmates hiding.

Once the participants were in Year 11 and they spent less of their time in the playground due to building work, the library became a place where many of them went during lunch times. Again, this was in part due to the comparative comfort that the room offered, but also at lunch time the room was policed by teaching assistants and administrative staff who were seen as easy targets by the students. In order to be allowed to be in the library at lunchtime the students were supposed to be quietly reading. Repeatedly, students were observed there at lunchtimes; some were picking up books or magazines at random as a justification for being there, while a minority would make no effort to pretend to be there to read at all. This was captured by field-notes: 
It's calm, but kids are sneaking around and clouting others round the head!

There's lots of laughter. They should be reading a book to be allowed here but, although many of them are holding books, very few actually reading them. It's obvious that they're not.

The above extract demonstrates that they were not doing anything particularly outrageous, just trying to get away with being there and finding the reaction of the teaching assistants funny. It was true that students were observed on occasion jumping on the beanbags, but this did not occur much, despite the perception of some of the students. For example:

Jenni: Yeah, and they tell us to get out and we were just sit on the sofa and we're chucking pillows everywhere... and like start jumping on these and they're going mad aren't they!! "Get out!!"

No actual observation took place recording anyone throwing anything, though fieldnotes made regular reference to teaching assistants shouting at students, much to the amusement of the latter. The stressed reactions of the teaching assistants gave the students the feeling of being in control of the situation, along with the sense that the adults in the room could not do anything about their behaviour. They totally dominated the space without ever doing anything sufficiently rebellious to warrant the presence of senior staff to deal with the behaviour. This reveals quite a nuanced understanding of exactly what they could get away with, without causing themselves significant trouble from the authorities in the school. It also reveals the importance of humour as part of their spatial strategies, identifying areas where humour could be used in order to reappropriate space.

Yet, despite liking to give the impression that they could create anarchic spaces, participants sometimes seemed to express a preference for order. During one interview, 
several of the participants in the study identified the library as being their favourite part of the school specifically because it did not appear as chaotic as everywhere else:

Elizabeth: It's actually a part of the school where it doesn't look like a building site.

Mark: Yeah... all the classrooms all look tatty.

They re-appropriated the library space in the absence of other clean and tidy areas for them to go. They were allowed to go into the library during their breaks in order to read but this was not their intention. This contrasted with participants' behaviour in Year 10 when they had occupied the skip. They had moved on to inhabit more comfortable spaces, discovering more genteel environments for resistance and subversion.

\section{Resistance, identity and survival}

As already observed, the partially rebuilt grounds caused resentment about the constant change, the interruption to studies and risks in view of academic outcomes. The sense of perpetual change fed into the students' disidentification with school as a place that they might wish to be (Morris-Roberts 2010; Skeggs 1997).

Simultaneously, the participants had carved out a group identity that they wanted to protect. The changes to the school threatened the survival of this identity that had been constructed. As Charlie recognised:

"They're trying to change the image of the school, but they're still.... but we're still going to the school. You can change the schools name, you can change the uniform, but you can't change us... the way we are."

Similarly, Jordan, was proud to announce that 'we got a bad reputation', added that 'the building int gonna change the people inside it is it?'. The participants wished to 
resist the changes that were being imposed upon their environment, enabling their survival.

Charlie: Like I was saying, change the name as many times as you want. Change the uniform as many times as you want. But you can't change the people in and around here.

Brandon: They shouldn't be able to change us. They can't change us.

Charlie: We're invincible.

This view of themselves as being beyond change and 'invincible' is an example of a defensive spatial strategy as described by Reay (2007). In order to conceive of themselves as good enough they carried out a psychic and spatial recoding to see themselves as survivors. The school and its inhabitants may be rubbish but they will survive, they cannot be changed.

The changes being enacted on the fabric of the school could not be stopped by the students even though they were resistant to the notion of them happening at all, and as a result the changes taking place became a conduit for resistance. This conduit allowed the students to move their attention away from their education and onto the building work, leading to such behaviour in lessons as complaining that the building work was unsafe, being more interested in the construction work than the lesson itself, complaining about the second-class nature of their school citizenship. This fits with the covert nature of much of their resistance rather than the overt and explicit transgression of rules producing not simply resistive acts, but a more general resistive mentality representing a collective frustration at that which was occurring around them and their lack of control over events.

\section{Discussion}

The responses of participants need to be considered in the context of the fluid 
environment around them; the building work contributing to a heightened sense of victimhood. Not only was it perceived as being disruptive to their education; it was an affront to them as a group because they constructed their own identities around it. The mercurial nature of the environment, with its constant changes due to the incessant building work, was perceived by some participants as an effort to re-invent not only the school site but its students. This was resisted through a defensive spatial strategy of perceived invincibility.

We were struck by the equivocal nature of the psychological associations of specific spaces. At times participants expressed feelings that suggested a sense of low worth through association with dilapidated spaces; on the other hand, there were times when such spaces seemed to enhance self-esteem through association with wildness and imagined danger. Although the participants were keen to highlight the perceived impoverishment of their landscape, they revelled in their own sense of toughness; they had survived here and claimed ownership of the surrounding spaces. Those spaces, such as the skip, may have been marginalised, but they were theirs.

There was something beyond opportunism at work. Even in Year 10, participants were discussing planned changes to spatial behaviour in the following year. Once in Year 11 they infiltrated some of the safe spaces, such as the library, introducing new behaviours in such spaces. Over the two years, their in-group (Tajfel \& Turner 1986) gained a sense of superiority through these acts of survival and subversion.

Nevertheless, the participants in this study displayed a curious mixture of helplessness and agency. There was also ambivalence in their feelings about a learning environment. On the one hand, they viewed the spaces around them as oppressive, subject to constant change. They expressed a desire for continuity, so that the environment could support their own study. At the same time, they often did everything 
possible to disrupt the environment, appropriating and re-defining spaces so as to challenge authority

In describing the spatial environment, the youngsters in this study utilised a language of resistance and conflict (Deleuze 2004; Foucault 1988). Through their language, they portrayed the landscape around them as chaotic and wild: the chaos, in their view, caused by external decisions, and the wildness a response indicative of their free spirit. While glorying in the sense of anarchy, they also seemed to yearn for order.

They saw themselves as the victims not the agents of the changes in the site that were occurring around them. These changes to the school buildings constituted both a threat and an opportunity. The changing environment was perceived as eroding and undermining their identity. In response, they sometimes became fatalistic or intransigent, viewing themselves as beyond change. However, an alternative response was to express defiance - being beyond change also made them, in some way, invincible. There was a constant fluidity, and the changes that were taking place opened cracks in the discourse surrounding them, enabling them to make further claims to available spaces and re-appropriating them through their behaviour.

The shoddiness of the spaces allocated was the cause of complaint and yet the source of delight. The participants perceived themselves as 'outsiders'; the space that was being created in the school grounds was part of a masquerade, of no benefit to them. They identified the school, and later themselves, with the bins, which they photographed repeatedly, so as to make the point. Theirs was the kingdom of the 'skip', a place where rules did not exist and where separate identities could evolve ungoverned by authority figures.

The participants used space to affirm their group bonds and assert collective identities. We are cautious about interpreting their actions as tactics or as strategies, 
fearing that this could lead to simplification. Where groups become isolated within their environment, strategies and tactics become particularly important (De Certeau 1984), but we do not feel that the binaries of De Certeau are applicable. De Certeau (1984) distinguished between strategy and tactics by suggesting that those with power behave strategically in space; whereas those that do not, resist tactically through time. Spatially subversive acts (Bell \& Valentine 1995) carried out by students disrupt orthodox use of space enabling its re-appropriation. These would be seen as tactical acts of resistance by De Certeau, contained within a strategic control of space by more powerful forces. However, such a view relies both on a dichotomous understanding of power (questioned through the work of Foucault) and a separation of space and time (challenged through the work of Massey). The power that students have to construct place through their resistive and spatially subversive acts needs to be understood through a lens that avoids the conceptualisation of power as monolithic, and of resistance and power as a binary split.

The actions of the participants strike us as being more than the tactics of the weak. Through their actions the students were not simply employing tactics to resist an oppressive, and to their mind, uncaring institution. They were exploring understandings of themselves through spatial experimentation. Rather than directly challenge authority they carved out, through their selection of language, separate conceptual spaces. They strengthened relationships and established a distinct group identity; perhaps, they even managed to construct a counter culture. As such, this all seems to constitute more of a strategy than a tactic, though it sometimes seemed too opportunistic and reactive for a 'strategy'.

To describe resistance as an anti-authority struggle is insufficient and Foucault $(1982 ; 2003)$ identifies the key characteristics of this opposition. People do not identify 
overarching enemies, but rather their immediate enemy: that which is closest to them and can exercise power over them. This means that the object of struggle is not to attack a specific institution or group, but rather specific instances and forms of power. Power places individuals into categories and imposes identity on them which they and others must recognise. It makes individuals subjects both in the sense of being subject to someone else and through being bound to their identity. The participants did not identify all-embracing enemies. They identified teachers and wider school authorities as their opponents, the people and institutions that directly exercised power over them. Their acts of resistance demonstrated their own power and served as critical aspects of their identity formation.

\section{Conclusion}

Through their actions, participants gave school a different meaning. They inhabited marginalised and abandoned spaces. The meanings they created for those spaces were often invisible to outsiders, or, perhaps, of little consequence. Later, they infiltrated and reconfigured established, safer and more contested spaces. The meanings of such spaces change with each new group entering them; indeed, the meanings can change each time the same group revisits those spaces.

In effect, by constructing shared meanings of specific spaces, the students in this study were achieving several things at the same time: an escape from an oppressive, sometimes hostile, sometimes dull, environment; engaging in playful interactions between themselves; challenging authority; reinforcing group identities and behaviours; and, by connecting themselves to marginalised spaces or even banishing themselves to such spaces, they were demonstrating both a sense of defeatism and 
ironic superiority. For each individual, however, different elements here would have had different nuances.

Perhaps, too, the findings of this study emphasise the failure of schools to establish spaces that are truly democratic and nurturing. Ways in which the school environment can shape behaviours is often overlooked, yet clearly, needs to be factored in (Benito 2003; O'Donaghue 2006). Perhaps, it would be pertinent to include the users and communities in the actual building process, so as to avoid alienation and to construct a genuinely shared and democratic environment.

\section{References}

Allen, Louisa. 2013. "Behind the Bike Sheds: Sexual Geographies of Schooling." British Journal of Sociology of Education 34 (1): 56-75. doi:10.1080/01425692.2012.704719

Bell, David, and Gill Valentine. 1995. Mapping Desire: Geographies of Sexualities. London: Routledge.

Benito, Agustín Escolano. 2003. "The School in the City: School Architecture as Discourse and Text." Paedagogica Historica: International Journal of the History of Education 39 (1): 53-64. doi:10.1080/00309230307462

Brown, Ceri. 2017. “'Favourite Places in School' for Lower-set 'Ability' Pupils: School Groupings Practices and Children's Spatial Orientations." Children's Geographies 15 (4): 399-412.

Borch, Christian. 2002. "Interview with Edward W. Soja: Thirdspace, Postmetropolis, and Social Theory." Distinktion: Journal of Social Theory 3 (1): 113-120. doi:10.1080/1600910X.2002.9672816

Casey, Edward. 1996. "How to Get from Space to Place in a Fairly Short Stretch of Time." In Senses of Place, edited by Steven Feld and Keith Basso, 13-52. Santa Fe: School of American Research.

Catling, Simon. 2005. “Children's Personal Geographies and the English Primary School Geography Curriculum." Children's Geographies 3 (3): 325-344. doi:10.1080/14733280500353019 
Christensen, Julie H., Lærke Mygind, and Peter Bentsen. 2015. "Conceptions of Place: Approaching Space, Children and Physical Activity." Children's Geographies 13 (5): 589-603.

Daniel, Paul and Ulla Gustafsson. 2010. "School Lunches: Children's Services or Children's Spaces?" Children's Geographies 8 (3): 265-274.

De Certeau, Michel. 1984. The Practice of Everyday Life. London: University of California Press.

Deleuze, Giles. 2004. Desert Islands and Other Texts 1953-1974. Los Angeles: Semiotext(e).

Deleuze, Giles, and Félix Guattari. 1988. A Thousand Plateaus: Capitalism \& Schizophrenia. London: Athlone.

Foucault, Michel. 1982. “The subject and power.” Critical Inquiry 8(4), 777-795.

Foucault, Michel. 1988. Politics, Philosophy, Culture: Interviews and Other Writings, 1977-1984. London: Routledge.

Foucault, Michel. 2003. Society Must be Defended. London: Penguin.

Gillborn, David. 1990. 'Race’ Ethnicity and Education. London: Unwin Hyman.

Gillborn, David and Deborah Youdell. 2000. Rationing Education. Buckingham: Open University Press.

Gillborn, David and Deborah Youdell. 2004. Teacher, Tests and Triage: Standards, High-stakes Testing and the Rationing of Education in the English Classroom. American Educational Research Association: San Diego.

Goodman, Steve. 2010. Sonic Warfare: Sound, Affect, and the Ecology of Fear. Cambridge: MIT Press.

Hall, Tom, Amanda Coffey and Howard Williamson. 1999. "Self, Space and Place: Youth Identities and Citizenship." British Journal of Sociology of Education 20 (4): 501-513. doi: 10.1080/01425699995236

Harper, Douglas. 1998. “An Argument for Visual Sociology.” In Image-based Research: A Sourcebook for Qualitative Researchers, edited by Jon Prosser, 2441. London: Falmer Press.

Kamberelis, George and Greg Dimitriadis. 2013. Focus Groups: From Structured Interviews to Collective Conversations. Oxford: Routledge.

Lefebvre, Henri. 1991. The Production of Space. Oxford: Blackwell. 
Massey, Doreen. 1995. "Places and Their Pasts.” History Workshop Journal 39: 182192.

Massey, Doreen. 2005. For Space. London: SAGE.

May, Tim. 2001. Social Research: Issues, Methods and Process. 3rd ed. Oxford:

Oxford University Press.

Morris-Roberts, Kathryn. 2010. “Girls' Friendships, 'Distinctive Individuality' and Socio-spatial Practices of (Dis)identification." Children's Geographies 2 (2): 237-255. doi:10.1080/14733280410001720539

O’Donaghue, Dónal. 2006. "Situating Space and Place in the Making of Masculinities in School." Journal of Curriculum and Pedagogy 3 (1): 15-33. doi:10.1080/15505170.2006.10411569

O’Donaghue, Dónal. 2007. “'James Always Hangs Out Here’: Making Space for Place in Studying Masculinities at School.” Visual Studies 22 (1): 62-73. doi:10.1080/14725860601167218

Pink, Sarah. 2009. Doing Sensory Ethnography. London: SAGE.

Prosser, Jon. 2007. "Visual Methods and the Visual Culture of Schools." Visual Studies 22 (1): 13-30. doi:10.1080/14725860601167143

Reay, Diane. 2007. “'Unruly Places’: Inner-city Comprehensives, Middle-class Imaginaries and Working-class Children." Urban Studies 44 (7): 1191-1201. doi:10.1080/00420980701302965

Rose, Gillian. 2007. Visual Methodologies. 2nd ed. London: SAGE.

Sack, Robert David. 1986. Human Territoriality: Its Theory and History. Cambridge: Cambridge University Press.

Schmidt, Sandra J. 2013. "Claiming Our Turf: Students Civic Negotiation of the Public Space of School.” Theory \& Research in Social Education 41 (4): 535-551. doi:10.1080/00933104.2013.840717

Sharp, Joanne P., Paul Routledge, Chris Philo and Ronan Paddison, eds. 2000. Entanglements of Power: Geographies of Domination/Resistance. London: Routledge.

Sibertin-Blanc, Guillaume. 2010. "The War Machine, the Formula and the Hypothesis: Deleuze and Guattari as Readers of Clausewitz." Theory \& Event 13 (3). doi:10.1353/tae.2010.0012 
Skeggs, Beverly. 1997. Formations of Class and Gender: Becoming Respectable. London: SAGE.

Smith, Dorothy E. 2002. "Institutional ethnography." In Qualitative Research in Action, edited by Tim May, 17-52. London: SAGE.

Soja, Edward W. 2010. Seeking Spatial Justice. Minneapolis: University of Minnesota Press.

Soja, Edward W. 1996. Thirdspace: Journeys to Los Angeles and Other Real-andImagined Places. Malden, MA: Wiley Blackwell.

Tajfel, Henri and John C. Turner. 1986. The social identity theory of inter-group behavior. In Psychology of Intergroup Relations, edited by Stephen Worchel and William G. Austin, 7-24. Chicago: Nelson-Hall

Tupper, Jennifer A., Terry Carson, Ingrid Johnson, and Jyoti Mangat. 2008. "Building Place: Students' Negotiation of Spaces and Citizenship in Schools." Canadian Journal of Education 31 (4): 1065-1092. doi:10.2307/20466739

Youdell, Deborah. 2004. "Engineering school markets, constituting schools and subjectivating students: the bureaucratic, institutional and classroom dimensions of educational triage." Journal of Education Policy 19 (4): 408-431.

Youdell, Deborah. 2006. Impossible Bodies, Impossible Selves: Exclusions and Student Subjectivities. Dordrecht: Springer. 